Annika Rockenberger

Editing a Discourse, Not a Text:

Meta-Methodological Remarks on an Editorial Endeavour

DOI 10.1515/jlt-2016-0014

Abstract: Whereas in literary studies poststructuralist theory (e. g. deconstruction, discourse analysis, broad concepts of intertextuality, 'Death of the Authorclaims and several versions of anti-intentionalism) has had - and still has - a massive impact on practices of interpretation, until now there has been very little reception of according ideas in the domain of scholarly editing. Here, emphatic criticism regarding the sauthor-centricity of textual scholarship rather employed concepts like stextual dynamics` or `textual fluidity`, as well as a positivist focus on the >materiality of singular documents.

However, within my contribution I will outline an entirely different approach by asking the question: If we actually decided to give up on author-centricity in scholarly editing and radically rejected authors' intentions as well as authors' single or collected works as objects of textual scholarship, could the yet unrealized project of sediting a discourse or sdiscourse edition` work as a complement, an extension, or a replacement of traditional editions?

To make this clear: So far there is no such thing as a discourse edition, so I cannot give a description of something already in existence. Actually, I don't want to make a case for discourse editions either, that is, my contribution will not contain any programmatic or normative claims and I will not suggest a concrete editorial concept. Instead, I will explore what questions and problems someone would be confronted with when seriously conceptualizing and/or realizing such a project. So, generally my presentation takes the shape of a heuristic (partly critical) thought experiment: the answer to a what-if-question.

One of the underlying ideas of this article is to confront contemporary edition philology (textual scholarship) - which is oriented towards categories like author, work, or text - with a sfoil \& for contrast specifically invented for the purpose to show quite plainly that those leading categories scholarly editorial work is based on are anything but self-evident and without any alternatives but in the end rather contingent (namely upon pragmatic considerations regarding research interests and overall aims of textual scholarship). Radically different modes of editing are

Corresponding author: Annika Rockenberger: University of Oslo, Department of Literature, Area Studies and European Languages, E-Mail: annika.rockenberger@ilos.uio.no 
imaginable and an editorial practice that is interested in asking different questions and pursuing different objectives would undoubtedly look very unlike what is the common practice and rationale of contemporary scholarly editing.

I designed a meta-philological thought experiment to exemplify exactly this and I will thereby reveal a discipline-specific methodological ıblindness`, irritate seemingly unproblematic habitual ways of thinking and thus uncover a deficit of reasoning and self-reflection in the field. Basically, I will clarify some implicit (categorial and methodological) presuppositions of scholarly editing and thereby uncover some aspects of the (invisible) normative framework underlying editorial practices.

Firstly, I will clarify what entities could be meant by the term >discourse focussing especially on French poststructuralism (namely Michel Foucault) - in order to establish the very object of a discourse edition.

Secondly, I will ask why - for what reasons and purposes - one should engage in such an enterprise at all: Why should one favour it over conventional editions? Would discourse editions be complementary to or an extension of alternative editorial options, or would they be their replacement?

When I will have shown that a discourse edition can actually be justified as a reasonable editorial project, I will move on to the question of how such an edition might look like. Hence, I will distinguish three versions of how to conceptualize a discourse edition - a weak, a strong, and a radical version each of which can be conceived as a complement, an extension, or a replacement of traditional editions: The weak version still focuses on author's single or collected works but also tries to reconstruct them as shubs « within historical discourse networks, e. g. by adding extensive commentaries, contexts and source material. The strong version comes closest to Foucault's programmatic ideas but also faces difficult questions, such as whether texts, parts of texts or statements are to be considered as the elementary units of a discourse edition, how exactly the quantity of editorially recorded objects is to be limited, and how different discourses are to be differentiated. The radical version - which turns out to be a prescriptive theoretical fiction - gives up not only on categories like sauthor`, ১work`, etc. but also dispenses with pretty much any other concept of order exceeding >free-floating s single statements, anonymous, and decontextualized.

Finally, I will briefly consider the question of how to practically realize the strong version of a discourse edition.

Keywords: textual scholarship, edition, discourse, author, Foucault, thought experiment 
In this essay I will discuss a potential editorial approach of how to get »beyond author-centricity“ (Gabler 2012), ${ }^{1}$ beyond the borders of single authors, works, texts and documents; and even how to get beyond categories like sauthor and ıwork ‘. Namely, I will explore a hypothetical project, which sometimes is labelled sediting a discourse

To make this clear: So far there is no such thing as a discourse edition in the proper sense, ${ }^{2}$ so I cannot give a description of something already in existence. Actually, I do not want to make a case for discourse editions either. Since my contribution is not a plea for or a defence of discourse editions, it will not contain any programmatic or normative claims, and I will not suggest and develop a concrete editorial concept. Instead, I will explore what questions and problems someone would be confronted with when seriously conceptualizing and/or realizing such a project. So, generally my presentation will be a heuristic (partly (critical) ${ }^{3}$ thought experiment: the answer to a what-if-question.

One of the underlying ideas of this article is to confront contemporary edition philology (textual scholarship) - which is oriented towards categories like author, work, text or even towards the sprimacy` of the singular document (cf. Gabler 2007) - with a >foil < for contrast specifically invented for the purpose to show quite plainly that those leading categories (and corresponding methodological premises) that scholarly editorial work is based on are anything but self-evident

\footnotetext{
1 An alternative approach to meeting this objective could be to shift the focus from authors and works to "the social dimension or context of book production or reading " (Kovacs 2007, 243), that is, to other functionaries of the literary system (cf. for an illustrative example Rockenberger 2011, 34-68).

2 It has to be pointed out, however, that there already are - in digital or analogue formats textual and multi-medial portals and archives of literary texts, historical source material, collections of letters and correspondences, linguistic corpora, etc. which are transcending the boundaries of single objects (text, work, œuvre). In part, these extensive collections might depict and reconstruct historical discourses as far as (1) the selection and organization of elements employs thematic, generic, formal, logical, rhetorical, spatiotemporal, cultural, socio-political, etc. criteria also relevant to the reconstruction of certain discourses, and (2) semantic structures, internal (intertextual) references, subliminal inconsistencies or underlying principles of arrangement get extrapolated. However, as far as I know, none of the existing projects draw on pertinent aspects of discourse theory in general or Michel Foucault's ideas in particular; for the most part,

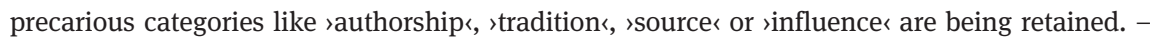
Still, future discourse editions might benefit from existing archives, portals, collections and corpora in a practical manner, especially when it comes to questions of data processing, text encoding, text mining, presentation, visualization, etc.

3 These terms were introduced by Popper who distinguishes between heuristic (to illustrate a theory), critical (against a theory), and apologetic (affirmative, in favour of a theory) thought experiments (cf. 1959).
} 
and without any alternatives but rather contingent (namely upon pragmatic considerations regarding research interests and overall aims of textual scholarship). Radically different modes of editing are imaginable and an editorial practice that is interested in asking different questions and pursuing different objectives would undoubtedly look very much unlike what is the common practice and rationale of contemporary scholarly editing.

I designed the following meta-philological thought experiment to exemplify exactly this and I will thereby reveal a discipline-specific methodological >blindness cover a deficit of reasoning and self-reflection in the field. Basically, I will clarify some implicit (categorial and methodological) presuppositions of scholarly editing and thereby uncover some aspects of the (invisible) normative framework underlying editorial practices.

Firstly, I will clarify what entities could be meant by the term >discourse focussing especially on French poststructuralism (namely Michel Foucault) - in order to establish the very object of a discourse edition. Secondly, I will ask why for what reasons and purposes - one should engage in such an enterprise at all: Why should one favour it over conventional editions? Would discourse editions be complementary to or an extension of alternative editorial options, or would they be their replacement? ${ }^{4}$ When I will have shown that a discourse edition can actually be justified as a reasonable editorial project, I will move on to the question of how such an edition might look like. Hence, I will distinguish three versions of how to conceptualize a discourse edition - a weak, a strong, and a radical version - each of which can be conceived as a complement, an extension, or a replacement of traditional editions. Finally, I will briefly consider the question of how to practically realize one of these versions.

\section{What Is a Discourse?}

Editions are oriented towards specific - primarily textual - objects of cognition. The fact that we verbally constitute certain things as objects and practically single them out as relevant for us might be explained historically, but in philological practice, it also calls for a justification. Why are we constructing the objects of

4 Another clarification in advance: As for this paper, I will refrain from engaging in any sort of (critical) >discourse analysis of editorial ideologies, basic assumptions, categories, concepts, or practices. 
textual scholarship the way we do? Why are we focussing on exactly these aspects of exactly these objects? (cf. Rockenberger/Röcken 2013, 128sq.)

With so called straditional editions, either stexts of documents works « are believed to be the primary objects of philological practices (cf. Tanselle 1992) - even if it isn't particularly clear what precisely is meant by terms like `work or stext and which ontological commitments are assumed thereby. However, what is clear is that it is about particular single objects with specific boundaries. Concepts

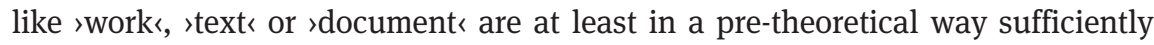
intelligible and can thus be used independently from professional definitions.

However, this does not hold true for the concept of >discourse term is in use in everyday language, where it is rather unclear, ambiguous, and vague. Even in the academic field - in philosophy, sociology, history, linguistics, and literary studies - one can find a number of competing definitions (cf. Mills 2004, 1-15). But principally, most relevant are the terminological stipulations of >discours as a (French) philosophical term Michel Foucault coined in the 1960s and detailed more specifically in his Archaeology of Knowledge (L'Archéologie du Savoir (1969)). Since most of the contributions to discourse theory and discourse analysis in some way or the other refer to Foucault's work, it seems to be natural - albeit not mandatory - to ensue from Foucault's definitional hints when putting forward an explicatory definition of the concept >discourse

A clarification of >discourse as a concept is necessary because of the following reason: Before one could inquire after the constituents and boundaries of a particular discourse, one has to know, what is a discourse in the first place; that is, one has to make sense of the very concept of a discourse. What kind of objects to focus on and reproduce in an edition - texts, parts of texts, single statements depends on the definition of the concept >discourse « as well as it depends on how those objects in principle would have to be characterized, limited, and isolated from other objects. Briefly speaking, the extension of the chosen concept of >discourse is the object of a discourse edition. A definition would have to provide criteria by means of which one is able to identify discourses and differentiate them, meaning: to limit the quantity of objects referred to as >discourse decide, if and why single objects - as constitutive elements of discourses - are counted among it.

Unfortunately, Foucault's terminological stipulations are far from being clear, but instead rather vague, ambiguous, and in some cases contradictory. However, Foucault was fully aware of this indiscriminate use of key concepts when he confessed to have "used and abused « the term >discourse » in many different senses« $(2010,107)$. 
Lastly, instead of gradually reducing the rather fluctuating meaning of the word `discourse`, I believe that I have in fact added to its meanings: treating it sometimes as a general domain of all statements, sometimes as an individualizable group of statements, and sometimes as a regulated practice that accounts for a certain number of statements[.] (ibid., 80)

In this quotation alone there are three different stipulations of the concept >discourse «. For one thing, the comprehensive but unorganized »totality of all effective statements (whether spoken or written)« is referred to (ibid., 27); although, the talk of a "general domain « suggests that there could also be special domains and thus, that discourses could be located on different >levels` of generalisation. ${ }^{5}$

When - for a second thing - Foucault characterizes discourses as »individualizable groups of statements«, it becomes apparent that discourses can also be understood as transtextual complexes or pluralities of interrelated elements. As such, they are identifiable and distinguishable from different entities of the same kind (potential criteria for the identification and distinction of discourses are discussed in ibid., Ch.II.2).

With the third stipulation of >discourse that Foucault moves discourses from the level of linguistic entities to the level of linguistic practices "that systematically form the objects of which they speak" (ibid., 49). However, this kind of practice is not to be taken to refer to the rational activity of autonomously acting persons but rather taken as the production of material statements by anonymous ssubjects that is historically accidental and arranged or determined by certain regularities or rules.

I won't pursue this any further; but a detailed reconstruction would reveal that no less than a dozen different definitions of the term >discourse can be detected in the Archaeology of Knowledge (cf. Reisigl 2006). Foremost, the following definitions are of importance:

5 Actually, the issue is even more complex. The concept of >discourse Foucault suggested in Archaeology can be described as dualistic. Behind the contingent "forms of continuity « and regularities of historical discourses there is a »vast field «, and »the material with which one is dealing is, in its raw, neutral state, the population of events in the space of discourse in general« (2010, 26sq.). Foucault's aim is not only to suspend our own (present) historiographic discourse in order to reconstruct the historical one (and its categories); but to suspend (or simply ignore) the historical discourse as well to set frees an unstructured, pre-discursive totality of all observable linguistic phenomena, and thus replace seemingly "natural, immediate, universal unities« with »a group of controlled decisions« (ibid., 29). At least since Nietzsche, Genealogy, History (1971) Foucault gave up on this idea in favour of a monistic conception of discourse (cf. 1998c). However, the question remains, whether a discourse edition should represent historical categories of particular discourses (as integral parts of the editorial object) or rather try to reconstruct the discourse behind $\gg$ the discourses 
We shall call discourse a group of statements in so far as they belong to the same discursive formation; [...] it is made up of a limited number of statements for which a group of conditions of existence can be defined. (Foucault 2010, 117; cf. ibid., 107)

[D]iscourses [are] not [to be treated] as groups of signs [...] but as practices that systematically form the objects of which they speak. Of course, discourses are composed of signs; but what they do is more than use these signs to designate things. It is this more that renders them irreducible to the language and to speech. (ibid., 49, emphasis in the original)

What adds to the ambiguities and apparent contradictions is that key terms like >discourse`, sarchive`, >discoursive formation`, ssystem of formation` or >discoursive practice are often defined inversely and used synonymously. What's more, vague terms on the analytical micro level - especially the term statements (énoncé) - are used to define vague terms on the macro level.

So, for the person who attempts to conceptualize and prepare a discourse edition, there are basically three ways of reacting to the challenge of these terminological uncertainties: (1) One can submit oneself slavishly to the authority of sthe master and have a try on a scrupulous (and charitable) exegesis of Foucault's work. (2) One can make use of Foucauldian categories and concepts in a selective and eclectic way for one's own purposes, and in doing so follow Foucault's invitation to use his books as »tool boxes« $(1996,149)$. (3) One can propose one's own explicatory definition of the concept >discourse < with a loose connection to Foucault or completely detached from his definitory suggestions. A rather general suggestion of an explication that still is based on Foucault could look like this (cf. for another attempt at reconstruction Titzmann 1989, 51-53): ${ }^{6}$

From now on, the term >discourse r refers to the finite number of semiotic events (produced regularly or according to specific regularities) that not so much (thematically) refer to a distinct shared object but rather presuppose its existence practically.

6 There are ontological questions I will not deal with here (cf. Landwehr 2009, 20sq., and, for the comparable case of genres, Zymner 2003, Ch.3): Do discourses even exist or are they merely theoretical, hypothetical constructs? If the latter were the case: how could discourses cause certain statements? Does a (or at least: the) discourse exist prior to its (?) analytical reconstruction? Does the term sdiscourse denote an (identifiable and operative) entity on the level of historical reality or an entity that is located on the level of description and analytical (re-) construction? More briefly, is >discourse or the name for a described object? If the former were the case: how could we draw a clear distinction between the controlled analytical level of description (১their discourse $\triangleleft$ ) and the level of our own communicative practices (`our discourse`)? How could we avoid equivocations of pivotal terms? 


\section{Discourse Editions - Why?}

I want to get on to the more fundamental question of justification of such an editorial endeavour before dealing with the methodological questions of a practical realisation and discussing whether texts, parts of texts, or statements are to be considered as the elementary units of a discourse edition, exactly how the quantity of editorially recorded objects is to be limited, and how different discourses are to be differentiated.

I distinguish between negative and positive strategies of justification: At least since G. Thomas Tanselle's article on >Varieties of Textual Scholarship (1995) and Peter Shillingsburg's reflections on >Forms >Orientations to Text ` (2001) we are aware that there are various valid kinds, types, or forms of editions that are bound to various research perspectives and aims as well as they are bound to specific ontological and methodological premises. Moreover, they record different aspects of primary editorial objects, enrich them with metadata and present them. Key editorial concepts like stext ` and `work contain the aims, orientations, and programmes of editing in a nutshell (cf. Röcken 2008, 25-27, and 35sq.; Rockenberger/Röcken 2013, 98-101, and 128sq.).

This normative pluralism of textual scholarship is due to the positive strategy of justification I talked about. The specificity of editorial projects can be legitimized with reference to the wants, needs, and interests of editors and potential users of scholarly editions. And usually it depends on these interests which aspects of editorial objects are considered in the given situation.

However, as Jerome McGann pointed out in his Critique of Modern Textual Criticism (1983), editorial pluralism has its limitations in what I would want to describe as a negative or critical strategy of justification. What I mean is, that the interests and aims that underlie specific types of editions as well as the according ontological and methodological premises could be criticized and discarded as unreasonable and epistemically irresponsible.

For example, the controversy between editorial intentionalists and antiintentionalists (cf. Mailloux 1982, Ch.4; Greetham 1999, Ch.4) can't simply be decided with reference to the differing interests, different aspects of editorial objects and relevant context information. As an intentionalist, I can't just say: »Calm down! It is totally sound that you're not at all interested in the will and intentions of the author, the reconstruction of his work or its genetic context. However, what has this got to do with me? These are my interests! « Still, the antiintentionalist will keep on insisting that my attempt to sreconstruct the text of a 
workı as intended by the author is naïve (for epistemological reasons), condemned to failure and therefore irrational. ${ }^{7}$

For the project of a discourse edition the negative justification comes down to that: rejecting all or at least some alternative editorial conceptions as being impractical and misguided. In the light of the key epistemological premises of poststructuralism, the main bogeyman would be author-intentionalism or authorcentricity of editions. Most of all, the rejection of an external, pre-discoursive autonomous transmitter - as it reflects in the assertion of the sdeath or >disappearance of the author (cf. Barthes 2002a; Foucault 1998b) - is to be expected (cf. for critical reconstructions Nehamas 1986; 1987; Japp 1988; Lamarque 1990; Burke 1992; Freundlieb 1995, 310-317).

The key programme could be described as a de-ontologisation of entities set up as basic anthropological conditions or even natural necessities in support of a functional analysis of historically contingent discourse-internal categories. Thus, pivotal editorial categories - such as sliterature (cf. Köppe/Winko 2013, Ch.7.2),

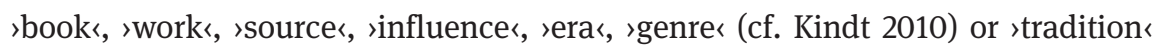
(cf. Foucault 2010, Ch.II.1; cf. for critical remarks Freundlieb 1995, 323) - are likely to be considered as part of the object range, rejected as categories of analysis and replaced with something else. Accordingly, elements of straditional editions, like annotations, editorial comments reconstructing the causal contexts of text production (including literary influences), collections of source material, genetic variants and authorial revisions, would probably be dismissed as well - or at the very least rearranged.

By way of contrast, the positive strategy of justification of a discourse edition only has to point out legitimate research interests and show that the editorial format of choice suits those interests best. To go into this in detail would take us too far afield. However, it should be clear that according to the research programme Foucault outlined in his Archaeology - a mere neutral descriptivism of surface phenomena, in his words: a >happy positivism` (cf. 2010, 125; cf. ibid., 2530) - indications could be drawn both in favour of a negative and a positive justification of a discourse edition.

7 Or, to put it that way: The anti-intentionalist critique impugns the practical rationality not of the means but the ends the intentionalist editor aimed for. Those ends are deemed cognitively deficient: the ends of editing that are pursued (»knowing the authorial intention concerning the textual form «) are impossible to realise and thus inherently misdirected. Another question which I will not dwell on is: are the epistemological standards that the anti-intentionalist implicitly underlays universally compellent or can a pluralism of incommensurable self-commitment be installed on this level, too? 
However, it should be kept in mind, that a counter-critique of such a project could be applied right here: Just think of Hubert Dreyfus and Paul Rabinow explicitly stating the "methodological failure " of the Archaeology in their by now classical reconstruction of Foucault's work (1982, Ch.I.4; cf. also the critical remarks in Brown/Cousins 2010). According to their argumentation, Foucault fails not only in making his project of a pre-categorial >pure Bühler/Schmitt 1983; Spoerhase 2007, 43-48) but also fails to provide an answer to his explanatory question of why at a specific moment in time exactly these statements occur instead of other statements - let alone their negation (cf. Foucault 2010, 27sq.; cf. for critical remarks Frings/Marx 2006).

Generally, there might be good reasons not to accept the theoretical and methodological premises of discourse theory and its (assumed) criticism of straditional scholarship. If one doesn't share the epistemological interests of discourse theory, but wishes to focus on the analysis and interpretation of single texts as products of intentional authorial agency, most of the data collected and presented by a discourse edition wouldn't be particularly relevant or helpful.

\section{Discourse Editions - How?}

What I want to do now is to distinguish three possible conceptions of a discourse edition to which I will refer to as a weak, a strong, and a radical version.

I am not entirely sure if the weak version would be considered as a discourse edition in a strict sense at all. Or if it would be more likely just discourse-oriented. An example of this type could be found in the Marburg scholarly edition of Georg Büchner's writings (cf. Büchner 2000-2013), where the editors are basically author-oriented and focus on single works but understand those works as knots in a net of specialized discourses (like religion, psychiatry, military and poverty). The lemmatized annotations, commentary, and documentation of source material aim at a visualisation of the works' location within different discourses and the effects of those discourses within single passages of the works. Categories like >influence and ssource are not abandoned but complemented with the discourse category. Apart from vertical (asymmetric) intertextuality, a rather unspecific concept of horizontal (symmetric) intertextuality is employed (cf. Dedner 1993; the distinction between horizontal and vertical intertextuality was introduced in Fiske 2010, Ch.7). Besides that, not only relations to shigh literature are reconstructed but trans-generic contextualisation is demonstrated, too.

In comparison, the strong version of a discourse edition is not limited to single authors, documents, texts, or works but could assemble and record larger quantities of linguistic units that presuppose the existence of specific objects as part of a 
regular or regulated practice. An edition like that would on the level of reconstruction and representation of the discourse most likely dispense with (disciplinary, generic, genetic, causal etc.) categories like ıgenre`, sauthor`, ıworkı, ısource`, stradition or sinfluences etc. It would operate with a broad concept of intertextuality (cf. for a critical reconstruction Irvin 2004) and abandon traditional (asymmetric) text-context-hierarchies. However, such a discourse edition in a strong sense would be confronted with practical problems. I will get back to that later.

Now, I try to imagine the radical version of a discourse edition that will turn out to be a prescriptive theoretical fiction when looked at more closely. I call that sthe Barthesian phantasm`. However, I am not sure if something like that could be practically realized at all. This virtually utopian main idea - based on a specific prescriptive theory of literature and literary reception (helpful reconstructions can be found in Spoerhase 2007, 18-37, and Allen 2000, Ch.2) - is inspired by Roland Barthes' ideas (cf. particularly 2002a; 2002b; 2002c; 2002d). In the concise wording of Paisley Livingston, it goes like this:

[L]et us try to imagine a world of textuality devoid of the sauthor function<. [...] We have to strip away all the proper names, as well as all the dates and any other information that could possibly have the function of anchoring the different morsels of textuality to a particular agent and particular context of production. Once this has been done, the resultant string of sentences would no longer be interrupted by sillusory، connections between authors and texts, and readers would no longer have any way of reliably linking chunks of text with knowledge about individual or collective authors. [...] [I]n general, textuality would be anonymous and decontextualized[.] (1993, 94sq.)

But still there might remain textual units at a certain level - sentences or paragraphs - that, when isolated as segments according to some category, might

have the effect of reinforcing the concept of work, for a single textual unit would be identified by reference to a single producer, [...] so there would still be a sense in which the text would be someone's work, and I might have the misfortune of starting to associate attitudes or even a personality with what I read. How could texts be catalogued and accessed without in any way relying on the categories of author and work? One solution would be to take all the world's books and articles and break them down to strings of randomly numbered, interspersed bits and pieces. (ibid., 95)

After that, these segments could be reorganized arbitrarily. But on the other hand, would whoever happens to determine the basic units and arrange them again be sthe author of something we might call sa workı?

It's hard to see how such an edition could be realized; and even if, it's even harder to see why anyone would want something like that. Simply because we (or at least some of us) are interested in such an object? Perhaps. A positive effect of this thought experiment could be to make one realize the contingency of philological categories while at the same time realizing the impossibility of perceiving 
anything without categories. A negative effect could be to make one aware that the price to pay for realizing an apparently chaotically rampant continuum of simultaneous units and symmetrical relations would be extremely high. Therefore, it seems to be a bit more down-to-earth to reflect about the practical execution of the strong version of a discourse edition.

To begin with: The limited number of all (ever and everywhere) factually produced statements can be recorded just as little as the number of statements that only survived and were preserved. Even a number of statements, reduced by matching them with discourses, would not be manageable at all. The same holds true for defining a specific discourse (let's say the German-speaking discourse on psychiatry in the late 18th century) as the object of an edition, for a somehow representative selection has to be made. The finding that a discourse like that existed and can be distinguished from other discourses is not a triviality. Because, adopting Foucault's proposal to leave all the functional categories on the object level out of consideration, one is confronted »in the first instance» only »with a population of dispersed events « $(1998 \mathrm{a}, 303)$ that will turn out to be related not until considerate (ıneutralı) inductive analysis. If we were initially assuming the existence of a particular discourse, we were anticipating the result of this analysis.

The selection of relevant units for the editorial discourse representation is another problem. According to which criteria are statements selected? Are they to be further qualified as >typical or >untypicalı, as `central or >peripheralı? Which statements are to be excluded (as redundant)? For what reasons? When does what amount of information in an edition count as a valid discourse representation? Above all: Prior to knowing what I want to reconstruct on the basis of the analysis of singular units, can I know at all if a single statement counts among or is representative for this plural unit? There's surely a danger of analytical circularity here.

This begs the question how exactly the basic units of a discourse edition are to be defined: Texts $^{8}$ seem to be unsuitable because normally they consist of elements that can be matched with different discourses. Also, texts seem to be categorially determined, and with the repetition of this discourse-internal unit on the level of reconstruction there could occur an invalid confusion of object level and analytical level.

8 Another general question is, whether discourse editions should also take account of nonpublished typographical texts and non-typographical entities (autographic constellations such as manuscripts, notes, drafts and fragments). If so, by what means should the latter be reproduced and represented? 
One alternative to this could be Foucault's category of sstatement ${ }^{9}$ (cf. 2010, 79117; cf. also the critical remarks in Bühler/Schmitt 1983, 221-223; Reisigl 2006, 100; Spoerhase 2007, 47sq.). But, even if this vague concept could be clearly defined and we had clear criteria of identification and distinction: ${ }^{10}$ Are statements to be decontextualized or are they (always) prone to further contextualization? Foucault seems to indicate that contextual factors could truly affect the identity of statements (cf. 2010, 96-104); and the same holds true for material aspects, at least in some cases (cf. ibid., 100-105; Jacobs 2009). So, are non- and paraverbal features to be considered? Or are statements purely linguistic (allographic) entities? ${ }^{11}$ What about pictures, sound recordings, and material artefacts? What about multimodal semiotic systems, multimedia, and intermediality?

9 Here, I take no account of the differentiation between the concepts of sstatement (énoncé) and senunciation ‘ (énonciation). The underlying logics of this conceptual pair can be reconstructed as some sort of type-token-relation, albeit undecided between a contextualist and a structuralist approach (cf. Foucault 2010, 101-105; further debate can be found in Angermüller 2007a, 106139, 2007b, 59-67, and Vogl 2008).

10 As for the project of a discourse edition, other pivotal questions are: Shall we be focusing on statements or enunciations? Are enunciations suitable to being captured by editorial representation at all? Are they rrepeatable ? What about statements? Does the editorial reproduction of a certain statement - its transfer from one material document to a second, from one context to another - have any bearing on its identity? In principle, Foucault concedes "possibilities of reinscription and transcription« $(2010,103)$; choosing examples from book publishing and editing, he points to cases where »the whole texture of the materiality has changed « but still »these ssmall differences are not important enough to alter the identity of the statement and bring about another (ibid., 102). Consequently, it seems as if any attempt at conceptualizing a discourse edition has to find a way to constitute »a locus of exact equivalence for the statements « and »an authority that permits repetition without any change of identity« (ibid.).

11 It is crucial to realise this: Like any edition (cf. Rockenberger/Röcken 2013, Ch.II.2), a discourse edition would have to start at the concrete materiality of the documents. Like any other edition, the discourse edition would too be confronted with the problem that a complete, exhaustive reproduction (a form of `cloning`) of the original document is impossible (cf. Röcken 2008 , 41). No edition can ever be identical with its object but only be its partial representation. As Hans Walter Gabler put it: »[0]riginal documents possess features which no edition [...] can exhaust; since they are in truth unamenable to editing. An original document is an autograph, and thus uncopyable and unreproduceable. Conversely, it is an allograph [...] in respect of its text alone [...]. As a document, it is unique. An original document is in fact unique in every respect save that of the intelligibility of its text.« $(2007,198)$ Because data selection and reduction are in any case inevitable in the process of editorial transposition (from one kind of materiality into another one), the question remains if a discourse edition should reduce its scope to the diplomatic reproduction of allographical linguistic sign sequences or if specific aspects of materiality - by means of digital facsimile, reproduction, description, or analysis - should also be recorded (cf. Röcken 2008, 45sq.). It could be decisive to demonstrate that material factors as well as contextual factors have in fact a bearing on the identity of statements. 
And as for the matter of editorial presentation: According to which principles are the single elements of a discourse edition to be internally arranged? How are intertextual relations between statements of one discourse or statements of different discourses to be recorded and presented? Is the presentation of a discourse to be extended to include an editorial meta-discourse, like a commentary or annotations? As for the latter, one should keep in mind Foucault's scepticism concerning >controlling « meta-discourses which try to »inscribe to the discourse a particular (allegedly more familiar) order « (Japp 1988, 232; my translation, A.R.), thus distracting recipients from irritating events that might have appeared (and should have been perceived) as effects of an unfamiliar discourse. For the very same reasons - let alone the strong anti-intentionalist leanings of poststructuralism in general, and the empiricist leanings of Foucault's Archaeology in particular - we shouldn't expect any engagement with textual criticism.

Another problem area (I won't be dealing with here) is the possible connection between discourse theory and humanities computing: At least there seems to be a certain affinity between the strict descriptivism of discourse analysis and the strict documentary orientation ${ }^{12}$ very common amongst digital scholars (cf. e. g. Haugen 2006 or Pierazzo 2011). However, are forms of digital archiving and editing to a certain degree suitable for realizing a discourse edition ? $^{13}$ The sheer quantity of data seems to indicate that. Who would even try to do a print edition of a discourse? Who would want to abstain from hypertext and multimedia, from open access and collaborative working environments? Still, it is not exactly clear how text encoding and meta-data would have to look like to enable discourse editions as specifically filtered transformations of digital primary data. In any case, the question of selection and internal organisation of information remains to be answered; for obviously digital archives and epoch databases are not identical with the edition of sthe discourse`, still less with editions of single discourses.

To sum up, there are a lot of difficult questions to answer and a lot of decisions to make, which have to be justified with reference to discourse theory and its research programme. However, we can choose to do a discourse edition as well as we can choose to do a critical edition of a single work. Maybe the point is,

12 Accordingly, Paul Eggert suggested that some urgent challenges of poststructuralist theory are best met by shifting the primary focus of editorial attention from authors (and their works) to the basic level of documents (cf. 1998).

13 In analogy to this, Vitali-Rosati argues that Barthes and Foucault »did not provide the conditions for a shift towards a world without authors « because of their »inherent lack of concrete editorial practices different from the existing ones « whereas "today, in the case of digital texts, the authorial function is no longer necessary « $(2014,111)$ since texts could easily be accessed »based on an algorithm or on a set of links« (ibid., 112). 
as Peter Shillingsburg recently put it, »that scholarly editing entails understanding the consequence of every choice, and for that there is no single set of rules that will help anyone to edit in the right way« (2011, 24; my emphasis, A.R.).

\section{References}

Allen, Graham, Intertextuality, London 2000.

Angermüller, Johannes, Nach dem Strukturalismus. Theoriediskurs und intellektuelles Feld in Frankreich, Bielefeld 2007 (Angermüller 2007a).

Angermüller, Johannes, Diskurs als Aussage und Äußerung. Die enunziative Dimension in den Diskurstheorien Michel Foucaults und Jacques Lacans, in: Ingo H. Warnke (ed.), Diskurslinguistik nach Foucault, Berlin/New York 2007, 53-80 (Angermüller 2007b).

Barthes, Roland, La mort de l'auteur [1967], in: R.B., Euvres complètes. Nouvelle édition revue et corrigée, Vol. 3, ed. by Éric Marty, Paris 2002, 40-45 (Barthes 2002a).

Barthes, Roland, S/Z [1970], in: R.B., Euvres complètes. Nouvelle édition revue et corrigée, Vol. 3, ed. by Éric Marty, Paris 2002, 119-346 (Barthes 2002b). [S/Z. An Essay, transl. by Richard Miller, New York ${ }^{27} 2000$.]

Barthes, Roland, De l'œuvre au texte [1971], in: R.B., Euvres complètes. Nouvelle édition revue et corrigée, Vol. 3, ed. by Éric Marty, Paris 2002, 908-916 (Barthes 2002c). [From Work to Text, in: R.B., Image, Music, Text, transl. by Stephen Heath, New York 1977, 155-164.]

Barthes, Roland, Texte (théorie du) [1973], in: R.B., Euvres complètes. Nouvelle édition revue et corrigée, Vol. 4, ed. by Éric Marty, Paris 2002, 443-459 (Barthes 2002d). [Theory of the Text, in: Robert Young (ed.), Untying the Text. A Post-Structuralist Reader, transl. by lan McLeod, London 1981, 31-47.]

Brown, Beverly/Mark Cousins, The Linguistic Fault. The Case of Foucault's Archaeology, in: Mark Gane (ed.), Towards a Critique of Foucault. Foucault, Lacan and the Question of Ethics, New York 2010, 33-60.

Büchner, Georg, Sämtliche Werke und Schriften. Historisch-kritische Ausgabe mit Quellendokumentation und Kommentar, ed. by Burghard Dedner, Darmstadt 2000-2013.

Bühler, Axel/Rüdiger Schmitt, Über Michel Foucaults Methodologie der Ideengeschichte, Saeculum 34 (1983), 212-225.

Burke, Sean, The Death and Return of the Author. Criticism and Subjectivity in Barthes, Foucault and Derrida, Edinburgh 1992.

Dedner, Burghard, Quellendokumentation und Kommentar zu Büchners Geschichtsdrama >Danton's Tods. Versuch einer sachlichen Klärung und begrifflichen Vereinfachung, editio 7 (1993), 194-210.

Dreyfus, Hubert L./Paul Rabinow, Michel Foucault. Beyond Structuralism and Hermeneutics, Chicago, IL 1982.

Eggert, Paul, Social Discourse or Authorial Agency. Bridging the Divide Between Editing and Theory, in: P.E./Margaret Sankey (eds.), The Editorial Gaze. Mediating Texts in Literature and the Arts, New York 1998, 97-116.

Fiske, John, Television Culture [1987], New York ${ }^{2} 2010$.

Foucault, Michel, From Torture to Cellblock [1975], in: Sylvère Lotringer (ed.), Foucault Live: Collected Interviews 1961-1984, New York 1996, 146-149. 
Foucault, Michel, On the Archaeology of the Sciences. Response to the Epistemology Circle [1968], in: M.F., The Essential Works. Aesthetics, Method, and Epistemology, Vol. 2, ed. by James D. Faubion, transl. by Robert Hurley, London 1998, 297-333 (Foucault 1998a).

Foucault, Michel, What Is an Author? [1969], in: M.F., The Essential Works. Aesthetics, Method, and Epistemology, Vol. 2, ed. by James D. Faubion, transl. by Robert Hurley, London 1998, 205-222 (Foucault 1998b).

Foucault, Michel, Nietzsche, Genealogy, History [1971], in: M.F., The Essential Works. Aesthetics, Method, and Epistemology, Vol. 2, ed. by James D. Faubion, transl. by Robert Hurley, London 1998, 369-392 (Foucault 1998c).

Foucault, Michel, Archaeology of Knowledge [1969], transl. by A. M. Sheridan Smith, New York 2010.

Freundlieb, Dieter, Foucault and the Study of Literature, Poetics Today 16 (1995), 301-344.

Frings, Andreas/Johannes Marx, Wenn Diskurse baden gehen. Eine handlungstheoretische Fundierung der Diskursanalyse, in: Franz X. Eder (ed.), Historische Diskursanalysen. Genealogie, Theorie, Anwendungen, Wiesbaden 2006, 91-112.

Gabler, Hans Walter, The Primacy of the Document in Editing, Ecdotica 4 (2007), 197-207.

Gabler, Hans Walter, Beyond Author-Centricity in Scholarly Editing, Journal of Early Modern Studies 1 (2012), 15-35.

Greetham, David, Theories of the Text, Oxford 1999.

Haugen, Odd Einar, On the Diplomatic Turn in Editorial Philology, Presentation at The 13th International Saga Conference, Durham, 6.-12. August 2006 (unpublished).

Irwin, William, Against Intertextuality, Philosophy and Literature 28 (2004), 227-242.

Jacobs, Wilhelm G., Materie - Materialität - Geist, editio 23 (2009), 14-20.

Japp, Uwe, Der Ort des Autors in der Ordnung des Diskurses, in: Jürgen Fohrmann/Harro Müller (eds.), Diskurstheorien und Literaturwissenschaft, Frankfurt a. M. 1988, 223-234.

Kindt, Tom, Diskursanalyse, in: Rüdiger Zymner (ed.), Handbuch Gattungstheorie, Stuttgart/ Weimar 2010, 227-228.

Köppe, Tilmann/Simone Winko, Neuere Literaturtheorien. Eine Einführung [2008], Stuttgart/ Weimar ${ }^{2} 2013$.

Kovacs, Susan, Discourse Analysis and Book History. Literary Indexing as Social Dialogue, Variants 6 (2007), 243-262.

Lamarque, Peter, The Death of the Author. An Analytical Autopsy, British Journal of Aesthetics 30 (1990), 319-331.

Landwehr, Achim, Historische Diskursanalyse [2008], Frankfurt a. M. ${ }^{2} 2009$.

Livingston, Paisley, From Text to Work, in: Nancy Easterlin/Barbara Riebling (eds.), After Poststructuralism. Interdisciplinarity and Literary Theory, Evanston, IL 1993, 91-104.

Mailloux, Steven, Interpretative Conventions. The Reader in the Study of American Fiction, Ithaca, NY 1982.

McGann, Jerome J., A Critique of Modern Textual Criticism, Chicago, IL 1983.

McLean, Gerald, What Is a Restoration Poem? Editing a Discourse, Not an Author, Text 3 (1987), 319-346.

Miething, Christoph, Die Metaphysik des Diskurses. Anmerkungen zu Michel Foucaults ıL'ordre du discoursı, Germanisch-Romanische Monatsschrift 39 (1989), 457-464.

Mills, Sara, Discourse [1997], New York ${ }^{2} 2004$.

Nehamas, Alexander, What an Author Is, Journal of Philosophy 83 (1986), 685-691.

Nehamas, Alexander, Writer, Text, Work, Author, in: Anthony J. Cascardi (ed.), Literature and the Question of Philosophy, Baltimore, MD 1987, 267-291. 
Pierazzo, Elena, A Rationale of Digital Documentary Editing, Literary and Linguistic Computing 26 (2011), 463-477.

Polzer, Markus, Philipp Melanchthons Schrift `Widder die artikel der Bawrschafftı. Studien zu einer intertextuell und diskursanalytisch orientierten Edition, in: Jörg Jungmayr (ed.), Officina editorica, Berlin 2011, 163-184.

Popper, Karl R., On the Use and Misuse of Imaginary Experiments, Especially in Quantum Theory, in: K.R.P., The Logic of Scientific Discovery, London 1959, 442-456.

Reisigl, Martin, Sprachkritische Beobachtungen zu Foucaults Diskursanalyse, in: Brigitte Kerchner/Silke Schneider (eds.), Foucault. Diskursanalyse der Politik. Eine Einführung, Wiesbaden 2006, 85-103.

Rockenberger, Annika, Produktion und Drucküberlieferung der editio princeps von Sebastian Brants >Narrenschiff، (Basel 1494). Eine medienhistorisch-druckanalytische Untersuchung, Frankfurt a. M. 2011.

Rockenberger, Annika/Per Röcken, Interessengeleitete Datenverarbeitung. Zur Empirie der neugermanistischen Editionsphilologie, in: Philip Ajouri/Katja Mellmann/Christoph Rauen (eds.), Empirie in der Literaturwissenschaft, Münster 2013, 93-129.

Röcken, Per, Was ist - aus editorischer Sicht - Materialität? Versuch einer Explikation des Ausdrucks und einer sachlichen Klärung, editio 22 (2008), 22-46.

Shillingsburg, Peter, Scholarly Editing in the Computer Age. Theory and Practice, Athens, GA 1986.

Shillingsburg, Peter, Orientations to Text, editio 15 (2001), 1-16.

Shillingsburg, Peter, Forms, Ecdotica 6 (2009), 116-125.

Shillingsburg, Peter, The Semiotics of Bibliography, Textual Cultures 6 (2011), 11-25.

Spoerhase, Carlos, Autorschaft und Interpretation. Methodische Grundlagen einer philologischen Hermeneutik, Berlin/New York 2007.

Tanselle, G. Thomas, A Rationale of Textual Criticism, Philadelphia, PA 1992.

Tanselle, G. Thomas, The Varieties of Scholarly Editing, in: David Greetham (ed.), Scholarly Editing. A Guide to Research, New York 1995, 9-32.

Titzmann, Michael, Kulturelles Wissen - Diskurs - Denksystem. Zu einigen Grundbegriffen der Literaturgeschichtsschreibung, Zeitschrift für französische Sprache und Literatur 99 (1989), 47-61.

Vitali-Rosati, Marcello, Digital Paratext, Editorialization, and the Very Death of the Author, in: Nadine Desrochers/Daniel Apollon (eds.), Examining Paratextual Theory and its Applications in Digital Culture, Hershey 2014, 110-127.

Vogl, Joseph, Aussage, in: Clemens Kammler (ed.), Foucault-Handbuch. Leben, Werk, Wirkung, Stuttgart/Weimar 2008, 225-227.

Zymner, Rüdiger, Gattungstheorie. Probleme und Positionen der Literaturwissenschaft, Paderborn 2003. 